\title{
The Level of awareness of green marketing and its managerial implications amongst selected South African manufacturing Small, Medium and Micro Enterprises (SMMEs) in KwaZulu-Natal
}

\author{
Lawrence Mpele LEKHANYA \\ Durban University of Technology, South Africa \\ lawrencel@dut.ac.za
}

\begin{abstract}
The focus of this paper is to present an exploratory study on the level of awareness regarding green marketing and its managerial implications, among selected, South African Manufacturing Small, Medium and Micro Enterprises (SMMEs), in the province of KwaZulu-Natal (KZN). The concept of green marketing and thought provoking managerial implications are still an issue of concern in the South African manufacturing sector. The study aimed to explore the awareness levels about green marketing by selected South African manufacturing SMMEs in KZN, and the resulting managerial implications. Primary data was collected from 84 manufacturing SMMEs. This research was quantitative in nature and a questionnaire was used to collect data from SMMEs owners/managers in KZN. Findings of the research indicate that SMMEs in the study are aware of green marketing and its managerial implications. It further reveals that SMMEs' owners/managers indicate that the South African Environmental Act and Consumer Protection Act are additional factors that influence their businesses operations. The paper will benefit SMMEs owners/managers, SMMEs marketing managers, and affiliated stakeholders, by introducing a new understanding of green marketing and how to cope with the demand of new green marketing strategies. Most work on the Green Zone has concentrated on green products, with little emphasis on green marketing and its implications. The findings are limited by the study's exploratory, quantitative nature and small sample. Generalisation should be done with care and further research, with a large sample and consideration of other provinces, is therefore recommended.
\end{abstract}

\section{Keywords: Green Marketing; Awareness; Managerial implication; Manufacturing SMMEs; South Africa}

\section{Introduction}

The phenomenon of Green marketing has developed particular significance in the modern market, emerging in the developing and developed world as an important concept, and seen as an essential approach to assist with sustainable development (Shrikanth \& Raju, 2012). The green marketing concept emerged as a result of organisations interest in the environment (Hashem \& Al-rifai, 2011). The green concept and green marketing have had exponential growth over the last decades and it had a significant impact on the market and environment globally (Iravani, Zadeh, Forozia, shafarudin \& Mahroeian, 2012). Green marketing plays an important role in attracting new customers and customer retention (Aza, Nobahari, Bagheri, Esmaeeli \& Rikhtegar, 2013). It can be noted that, green marketing has become an important component of most companies' marketing process (Thakur \& Gupta, 2012). The importance of environmental stewardship is also emphasized by green marketing (Smith, Lawrence \& Richards, 2010). Nowadays people are highly concerned about environmental protection and are willing to consume those products which are environmentally friendly (Saxena \& Khandelwal, 2010). According to findings from recent studies, the protection of the environment is of great interest to consumers with a heightened concerned for the degradation of the environment (Juwaheer, Pudarah \& Noyaux, 2012). In this regard, Garden, in da Silva (2010) indicates that green will quickly become an important measure for companies and brands, and commendations based on environmental references will play a vital role in decisionmaking of consumers. Eco- friendly initiatives within marketing can therefore also encourage customers to instantly give back to the Earth (Williamson, 2013).

Problem statement: According to Mohanasundaram (2012), the lack of academic examination of environmental or green marketing is one of the main problems in green marketing. Prakash (2002) \& Ghoshal (2008) state that, because of the multi-disciplinary nature of the enterprise, the understanding of green marketing is still in its early stages. This is supported by Thakur \& Gupta, 2012) who state that the green marketing concept is gaining momentum but that the pace of adoption has been very slow. Much research has been conducted locally and abroad, with regard to a green environment but none 
indicate the level of awareness of green marketing and its managerial implications in the South African context. This holds true more specifically in manufacturing SMEs, with specific reference in KZN. Therefore, this article intends to address this problem.

\section{Aims and objectives}

Aims: The research aims to analyse and evaluate the level of awareness of green marketing and its implications, amongst selected South African manufacturing SMMEs in KZN.

\section{Objectives}

- Explore the level of awareness of green marketing amongst selected South African manufacturing SMMEs in KZN.

- Examine the managerial implications of green marketing amongst selected South African manufacturing SMMEs in KZN.

\section{Literature Review}

KwaZulu-Natal Manufacturing sector: Literature indicates that the shift to a green growth economy is exacting, especially on manufacturing firms, which includes SMEs. This refers to the fact that the manufacturing sector contributes, to a large extent, to global utilisation of resources and waste generation (OECD working party on SMEs and entrepreneurship (WPSMEE), 2010). The KZN manufacturing sector is the second largest in the country and South African manufacturing SMEs are considered to be economically feasible (KZN Manufacturing sector, 2014). According to Carroll \& Buchholtz (2000), the maintenance of an ecological balance in South Africa has been addressed by the King 111 Report, regarding the outcome of sustainability in the economic, social and environmental spheres. Both large and small businesses have to abide by the King 111 Report's principles, with regard to a green economy, as set out by Van Wyk \& Deegan (2009).

Environmental marketing evolution: The discussion of environmental marketing or green marketing dates back to the 1990s, when the definition of green marketing was held to be a management process that aims at holistically distinguishing, predicting and fulfilling the consumer and society's requirements in a manner that is both profitable and sustainable (Peattie, 1995). Finistera do paco, Raposo and Filho, (2009) echo the sentiment that the 1990s was the decade of the environment and that, in this time, consumer decisions were greatly influenced by social and environmental concerns.

Definition of Green Marketing: The strategies used to promote products in terms of green marketing are defined by Prakash (2002) as the use of environmental claims, either about the products' characteristics and features or about the processes, polices and systems of the companies that manufacture or sell these products. According to Polonsky (1994), a broad range of activities are incorporated in green marketing, which includes the modification of products, production process changes, and changes to packaging, along with alterations to advertising. Chen \& Chai (2010) broaden the definition of green marketing to include activities by firms that are apprehensive about environmental or green problems, and subsequently present goods or services that are environmentally sound, to establish satisfaction with customers and society in general. Bukhari (2011), in a recent review of green marketing, defines green marketing as the means of selling products and/or services founded on their environmental advantages, where the product or service may be in itself be considered as environmentally friendly or perceived in an environmentally friendly manner.

Importance of green marketing: Green marketing has become an important ingredient of most companies (Thakur \& Gupta, 2012). This is prompted by the fact that worldwide, environmental protection today is considered one of the main and most talked about agendas. Mishra \& Sharma (2010) maintain that the door of opportunity has been opened for companies by the development of green marketing, allowing products to be co-branded into separate lines, selectively extolling and ignoring the green-friendliness of specific products. Gurmeet (2013) identifies a broad range of activities incorporated under green marketing, including several that marketers should be aware of, such as product and advertising modification, as well as changes to the production process, and packaging.

Green marketing strategies: Another major influence on the marketing planning and implementation process today, is that of the environment, with specific mention of the environmental impacts on 
manufacturing, management, and marketing processes. This is based on measurements by entities ranging from scientists to regulators, as well as environmentalists at the grass-roots level, investors, and consumers (Coddington, 1993). Ottman, Stafford \& Hartman (2006) indicate that green marketing must satisfy two objectives: improving the quality of the environment and customer satisfaction. Green marketing mix: Kontic (2010) holds that green marketing literature currently only refers to particular facets of the marketing mix, but further states no recognised studies exist that provide guidelines on how to go about establishing a green marketing mix. Lee \& Park (2013) maintain that the awareness of green consumption culture is growing among both individuals and communities, and that marketing strategies also reflect this. Kinoti (2011) indicates that individuals and organisations can benefit from green marketing strategies, while simultaneously protecting the environment in order for sustainable development to be achieved. The marketing mix is a blend of marketing variables, used to appeal to and persuade consumers to engage in a business exchange with the organisation at a given consideration (Kotler, 2000). According to Engel (2008), the concept of a green marketing mix requires marketers to adapt the conventional marketing mix to achieve green marketing objectives. Saad (2009) identifies the following key elements as the green marketing mix's main components:

The Green Product: A product is a bundle of benefits offered to the market for a given price or consideration (Humphreys, 2008). Peattie \& Crane (2005) define a product as being 'green' when, in manufacture, use or discarding, its environmental and societal functioning, are considerably improved, relative to a traditional product. Smith, Lawrence \& Richards (2010) regard the main measures of a green product as being that of green design, green labelling, green packaging and green procurement. The idea of green marketing is that the concern of companies should be centered on what ensues during and after a product's usefulness (Gale, 2006). This concern or focus may be exhibited through the testing of ways in which reassessment and redesign of the life stages of the product are done (Horne, 2009). According to Sorensen \& Jacob (2007), there is a need to conduct a product life cycle assessment, which concentrates on environmental concerns in product development and design, also accounting for energy and material efforts in product fabrication and manufacture, utilisation, and disposal. Product life assessment will assist in managing a product's life stages in a manner that is environmentally friendly and eco-efficient (Sorensen \& Jacob, 2007). Eco-efficiency is understood to be the appropriate consumption or utilisation of natural resources, in such a way and time frame, as to afford nature the opportunity to renew itself (Horne, 2009).

Green pricing: Price is the value attached to a product (Engel, 2008). Green pricing is a strategy, which allows marketers to adjust their pricing structure in line with their investment in green efforts to allow sustainability of the organisation. Many environmentalists are concerned that product prices do not represent total environmental costs. For example, the costs of waste disposal are often incurred on a basis of fixed fees, without regard for the actual amount of waste that is generated. Along the same lines, the costs of environmental degradation or depletion are not accounted for by most countries' national accounting systems. In some cases, after-the-fact pollution control and remediation expenditure are included as income. The assertion that goods and services related to greater environmental damage should cost more, make up the basis of the majority of greener pricing decisions (Engel, 2008).

Governmental pressure: Activity relative to green performance is being strengthened in various ways. Companies are subjected to competitive pressure, in being expected to commit to green marketing strategies amidst rising cost of materials and energy. On the other hand, public pressure keeps on escalating and there is increased consumer antipathy to globalisation, coupled with a growing awareness that consumer demand can be increased through triple-bottom line practices (Kleindorfer, Singhal \& Wassenhove, 2005). Even though such efforts can incur substantial costs, the positive relationship between environmental performance and greater financial performance, competitiveness, and innovation benefit has also been established (Kassinis \& Vafeas, 2006).

Cost or profits issues: The manner, in which cost or profit issues may affect firms' environmental marketing activities, is the two-fold development of new industries. This can firstly happen, in that a technology for reducing waste is developed by a company that then sells it to other companies; or through the development of a waste recycling or removal industry (Yurman, 1994) 
Table 1: Profile of Usable Sample as per cluster

\begin{tabular}{lll}
\hline Area /cluster & Frequency & Percent \\
\hline Durban metropolitan areas & 10 & 12 \\
Pietermaritzburg metropolitan areas & 28 & 33 \\
Richard Bay areas & 14 & 17 \\
KZN North Coast areas & 15 & 18 \\
KZN South Coast areas & 17 & 20 \\
\hline
\end{tabular}

Table 1: Respondents were asked to indicate area/cluster of their businesses and what they do in their businesses. A questionnaire was used as the measuring instrument for this survey. The main questions are summarised in Table 2.

Table 2: Summary of Key questions

\begin{tabular}{|c|c|}
\hline Research Area & Questions \\
\hline Understanding & What is your understanding of Green marketing? \\
\hline Green marketing & $\begin{array}{l}\text { Response alternatives: Marketing strategies should take care of environment; } \\
\text { Packaging of the products should take care of people or animals' lives; Business } \\
\text { must take care of waste and depleted water resources produced during the } \\
\text { operations; Business pricing strategy should take care of hidden environmental } \\
\text { costs. Everything businesses do must comply with the South African Environmental } \\
\text { Act. }\end{array}$ \\
\hline
\end{tabular}

Green marketing Which of these activities of Green marketing have you used during the last 12 activities used months

Response alternatives: Eco-labeled products; Packaging designed to give green zone protection; Provided green products to our customers; Products with environmentally responsible packaging; Products that meet or exceed environmentally responsible criteria.

Importance of Green Green marketing created more awareness, environmental products and green marketing branded products

awareness

Environmental

Response alternative: 5-point Likert scale

factors influencing

Green marketing

practices

Impact of Green

marketing on

business operations

Managerial

Implications from

Green marketing

Green marketing Business has marketing strategies in place

strategies of

business

Which one of the following factors affects your Green marketing abilities/activities?

Response alternative: 5-point Likert scale

There is an influence of Green Marketing on business operations

Response alternative: 5-point Likert scale

Green Marketing has implications on management activities and abilities

Response alternative: 5-point Likert scale

Importance of Green

Response alternative: 5-point Likert scale

marketing to the

customer's

satisfaction

Other influencing

factors on Green

marketing, please

specify

\section{Methodology}

A survey was conducted in various metropolitan and urban areas of KZN, including Durban and Pietermaritzburg metropolitan areas, Richards Bay areas, as well as KZN north and south coast areas. Primary data was collected from 84 manufacturing SMMEs. A literature review was the source of information for the formulation of the questionnaire, and was developed with both closed-ended and 
open-ended questions. Space was provided for the inclusion of any information that might be relevant at the end of questions. A non-probability sampling method, in the form of quota sampling, was used to obtain the desired sample. Due to time and financial constraints, quota sampling was used. Data was analysed using Statistical Package for the Social Sciences (SPSS) program (Version) 21.0 to test the significance of the results and presented in figures generated from Microsoft Excel 2010. The final usable sample is shown in Table1.

\section{Findings}

The previous section provided a review of literature on problems experienced by South African manufacturing SMMEs. This section reports on the key findings from the research conducted. Completed questionnaires were received from 84 respondents $(n=84)$ who either own or manage a manufacturing enterprise in KZN province.

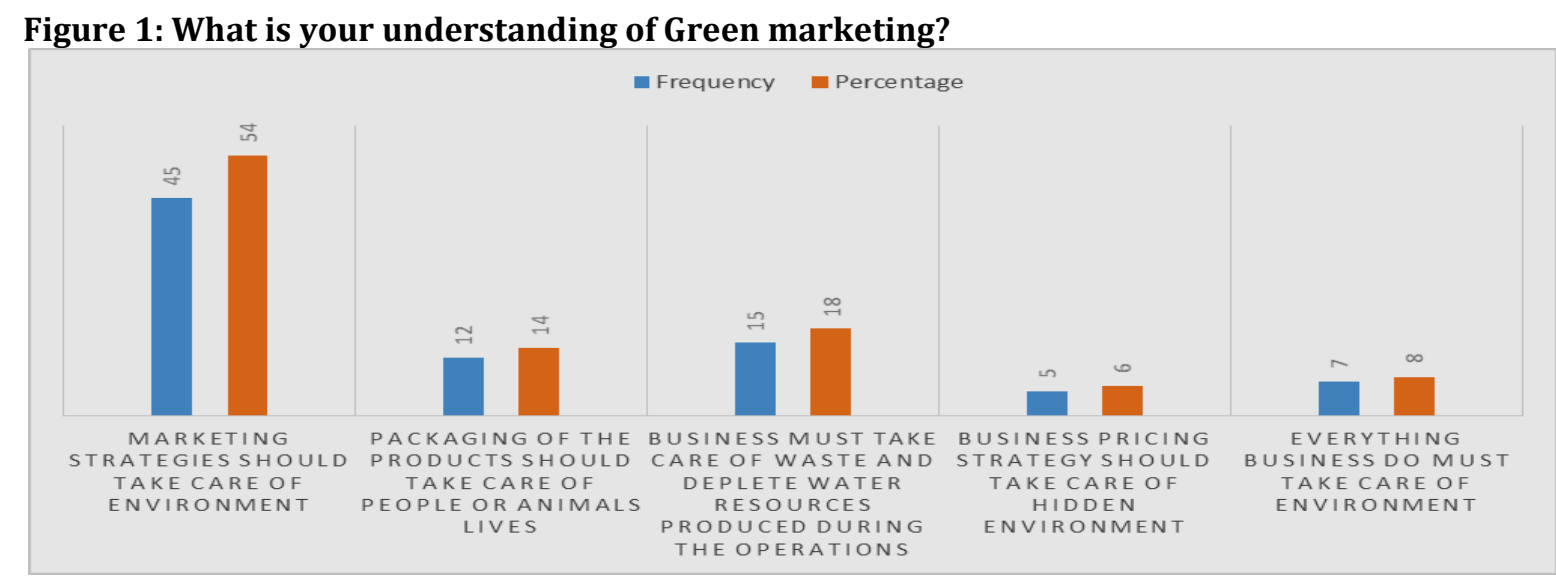

Marketing strategies should take care of the environment, Packaging of the products should take care of people or animals' lives, and Business must take care of waste and depleted water resources produced during the operations resulted in 45 (54 percent), 12 (14 percent) and 15 (18 percent)respondents respectively, indicating this as what they understood green marketing to be. Fewer respondent understood that green marketing also includes that the 'business pricing strategy should take care of hidden environmental considerations' and 'everything businesses do must take care of the environment', with five(six percent) and seven(eight percent)of respondents respectively indicating this as their understanding. A Chi-square test was conducted on the understanding of green marketing, how green marketing activities affected the company, and also, how much this affected green marketing awareness of the company. A Chi-square goodness of fit test showed this to be significant $(x=72.800, \mathrm{df}=16, \mathrm{P}=$ $.000)$.

\section{Figure 2: Which of these activities of Green marketing have you use during the last 12 months?}

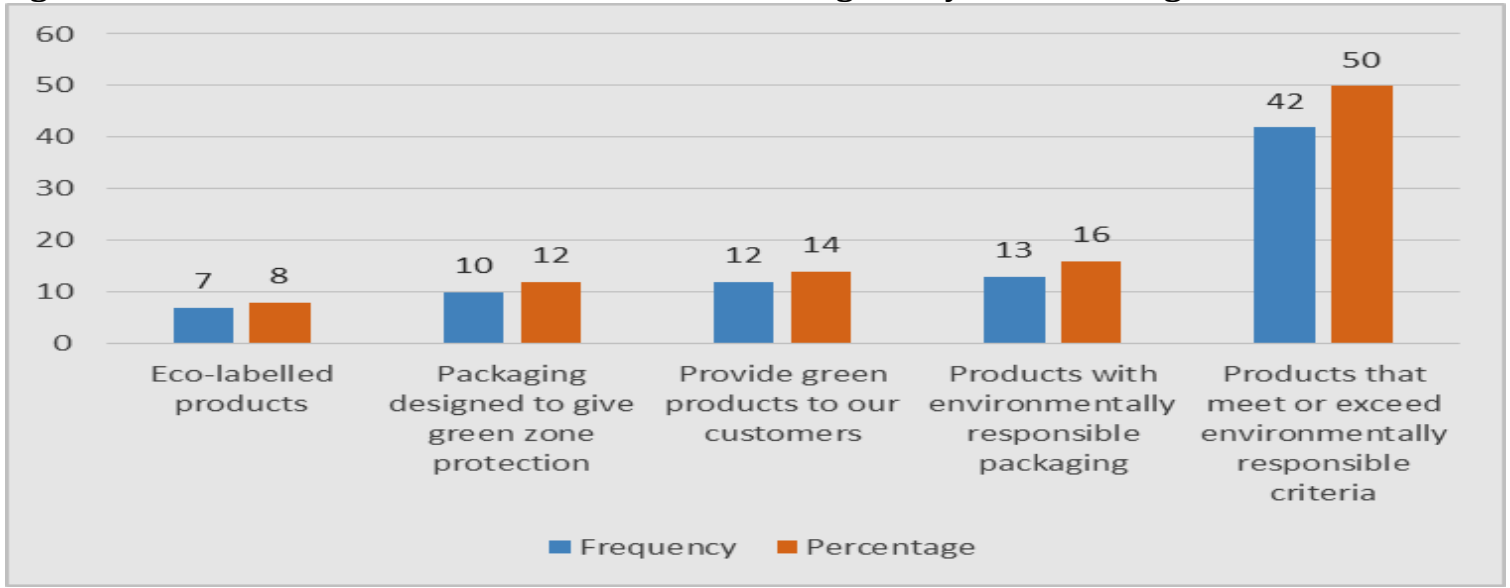

Products that meet or exceed environmentally responsible criteria were indicated by 42 (50 percent) respondents as the most considered activities during the last 12 months. The next most common were 
products with environmentally responsible packaging by 13 (16 percent) of the respondents, followed by similar frequencies, at 10 (12 percent) and 12 (14 percent). A Chi-square test was conducted in relation to the impact of green marketing on green marketing activities, which might be influenced by environmental factors. A Chi-square goodness of fit test showed this to be significant $(x=85.818, d f=16$, $\mathrm{P}=.000)$.

\section{Figure 3: Green marketing created more awareness}



A large number of respondents, at 17 (20 percent) and 38 (45percent), agree with the statement that there is convincing awareness of green marketing and green products among them. However, there is quite a considerable number of respondents, a total of 13 (16 percent), who are neutral about the awareness of green marketing. Very few respondents, 10 (12 percent) and six (seven percent), disagree that there is enough awareness of green marketing.

\section{Figure 4: Which one of the following factors affects your Green marketing abilities/activities?}

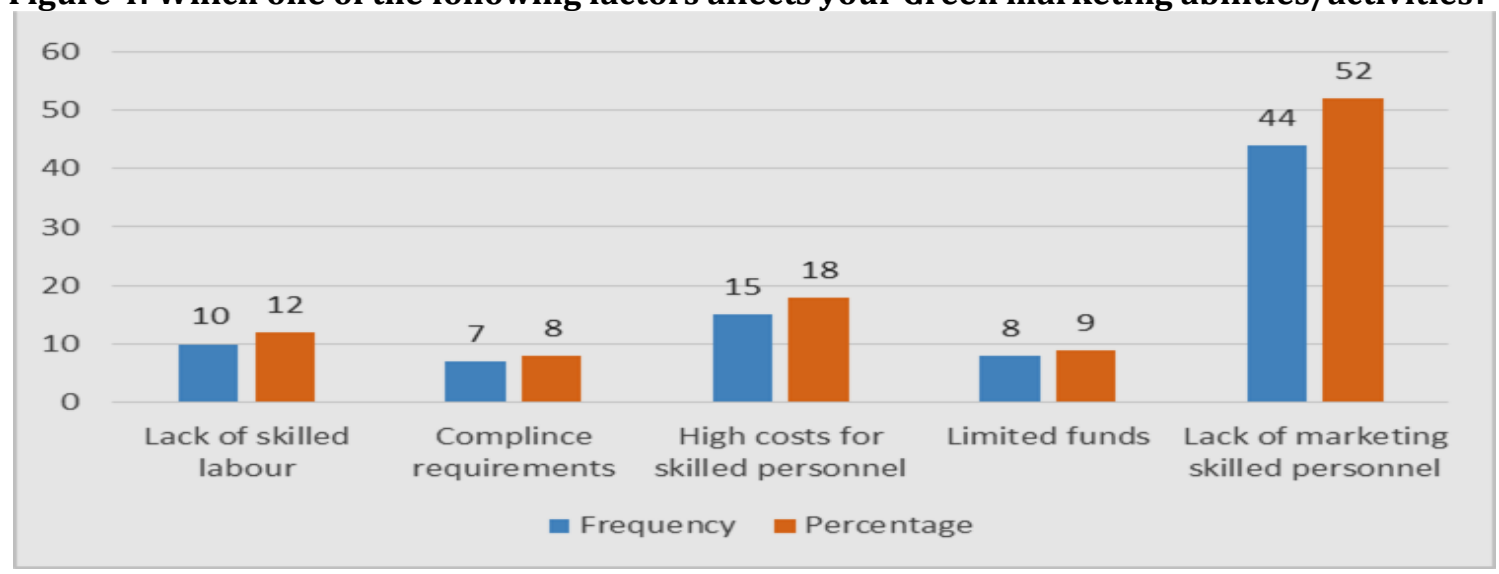

More than half of the respondents, 44 (52 percent) indicated a lack of marketing skilled personnel as the problem facing their companies, with regard to practicing green marketing. This was followed by high costs for skilled personnel, with 15 (18 percent) and 10 (12percent) respondents indicating a lack of skilled labour. Very few respondents mentioned compliance requirements; seven (eight percent) and eight (nine percent) respondents indicated limited funds as a factor. A Chi- square test was conducted on environmental factors' influence on green marketing and how they contribute to managerial implications of manufacturing SMMEs. A Chi-square goodness of fit test showed this to be significant $(\mathrm{x}=85.818, \mathrm{df}=$ $16, \mathrm{P}=.000$ ). 
Figure 5: There is influence of Green Marketing on business operations

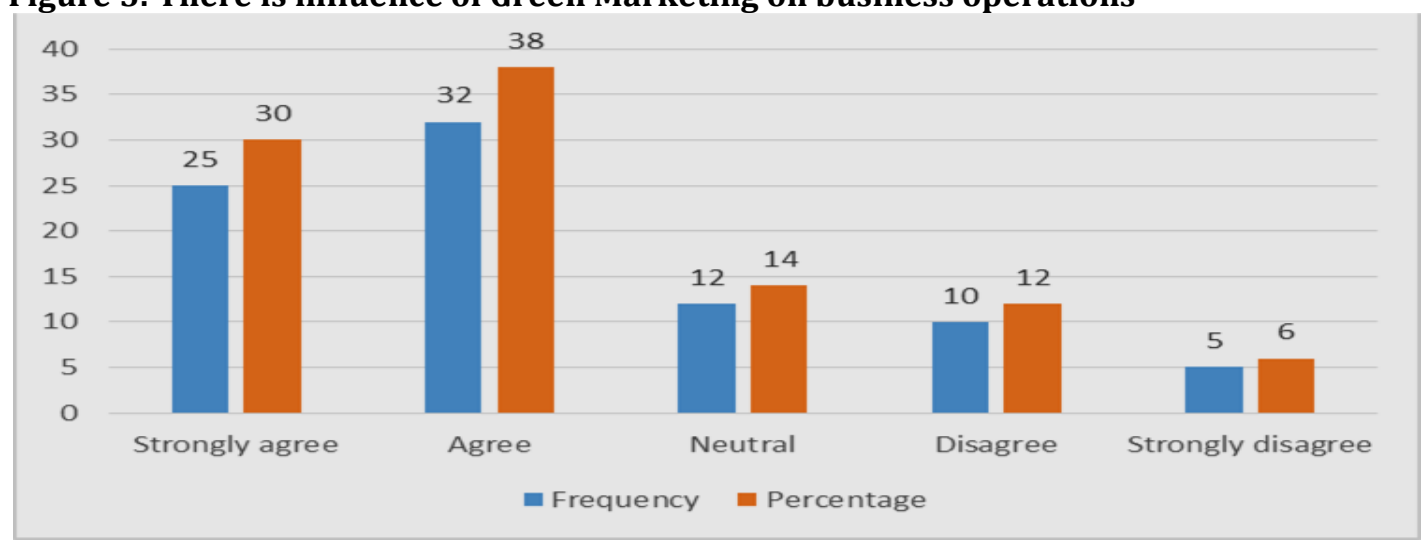

Figure 5 shows that there was a general feeling among the sample that there is strong influence of green marketing on their business operations with $25(30 \%)$ and 32 (38\%) of respondents agree with the statement. While very small percentage was either neutral or disagree that there is influence of green marketing on business operations.

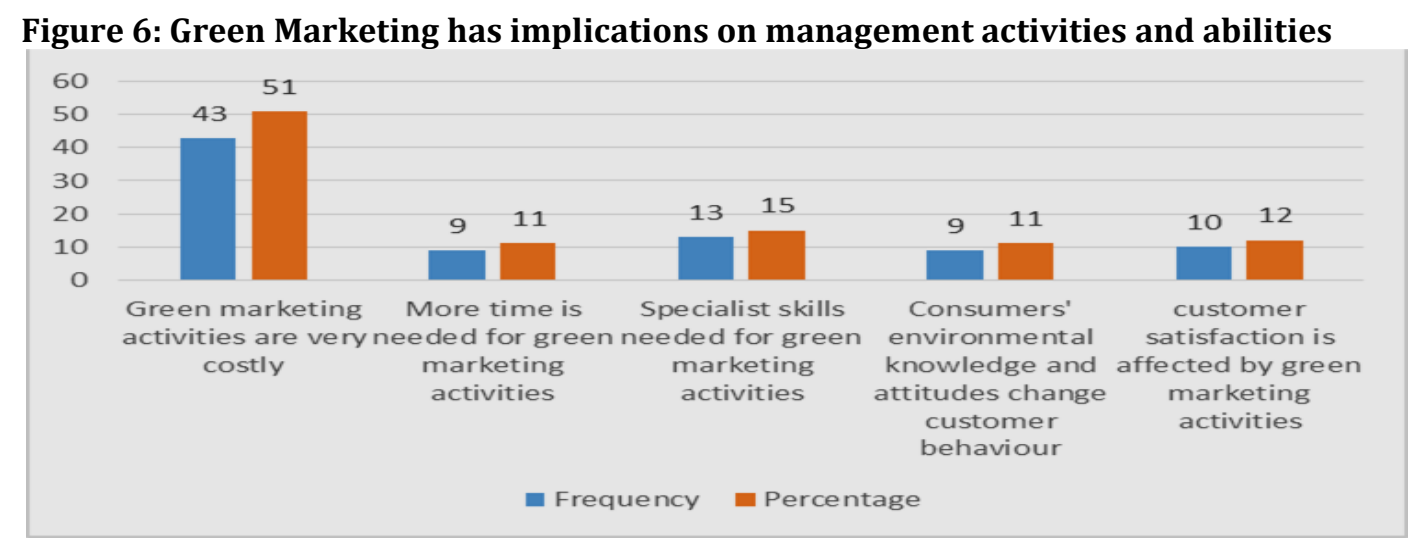

Cost of green marketing activities were indicated by 43 (51 percent) respondents, and time needed for green marketing activities by nine ( 11 percent) as the most frequently cited implications experienced by respondents, which makes sense, considering that the respondents have to hire specialists in order to meet IS900 standards, as stipulated in the South African Environmental Act. It has been noticed that some manufacturing SMMEs do not have marketing specialists, even though they employ people to deal with marketing related matters or to work in the marketing department. A considerable number, 13 (15 percent), of respondents highlight that specialist skills are needed for green marketing activities. While few respondents, nine (11 percent) and 10 (12 percent) respectively, believe that consumers' environmental knowledge and attitudes change customer behaviour and customer satisfaction is affected by green marketing activities.

Figure 8: Which of the following aspects of Green marketing affect customer satisfaction with the company's products?

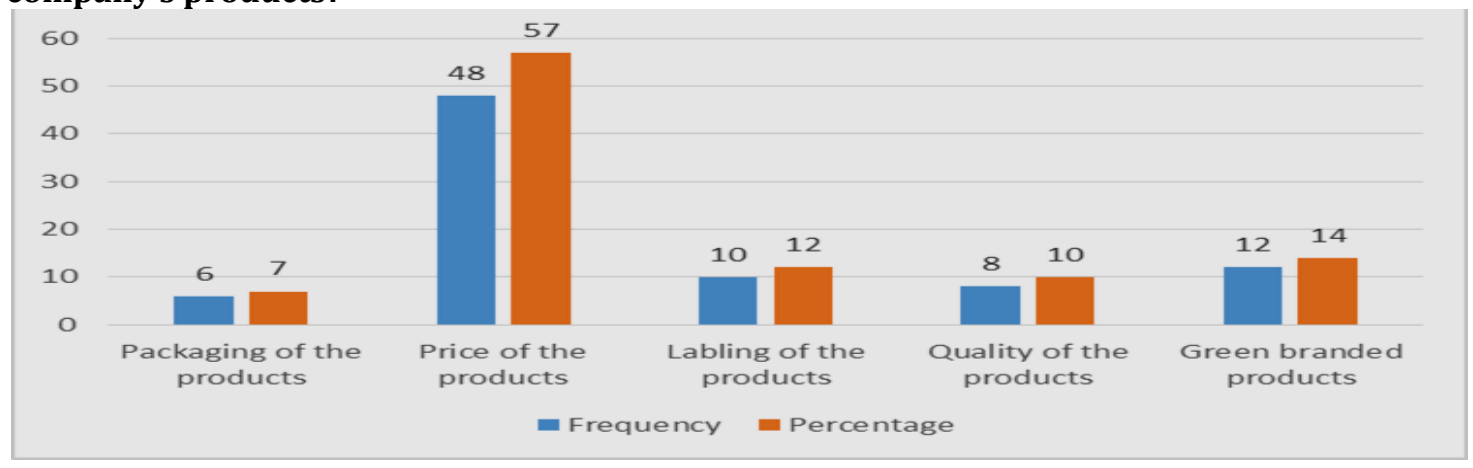


Figure 8 indicates that there are a number of green marketing aspects that affect customer satisfaction with the company's products. More than half of respondents' mention of the products as the main aspects of green marketing that affects customer satisfaction, followed by green branded products, quality of the products and labelling of the products.

\section{Figure 9: Other factors affecting green marketing}

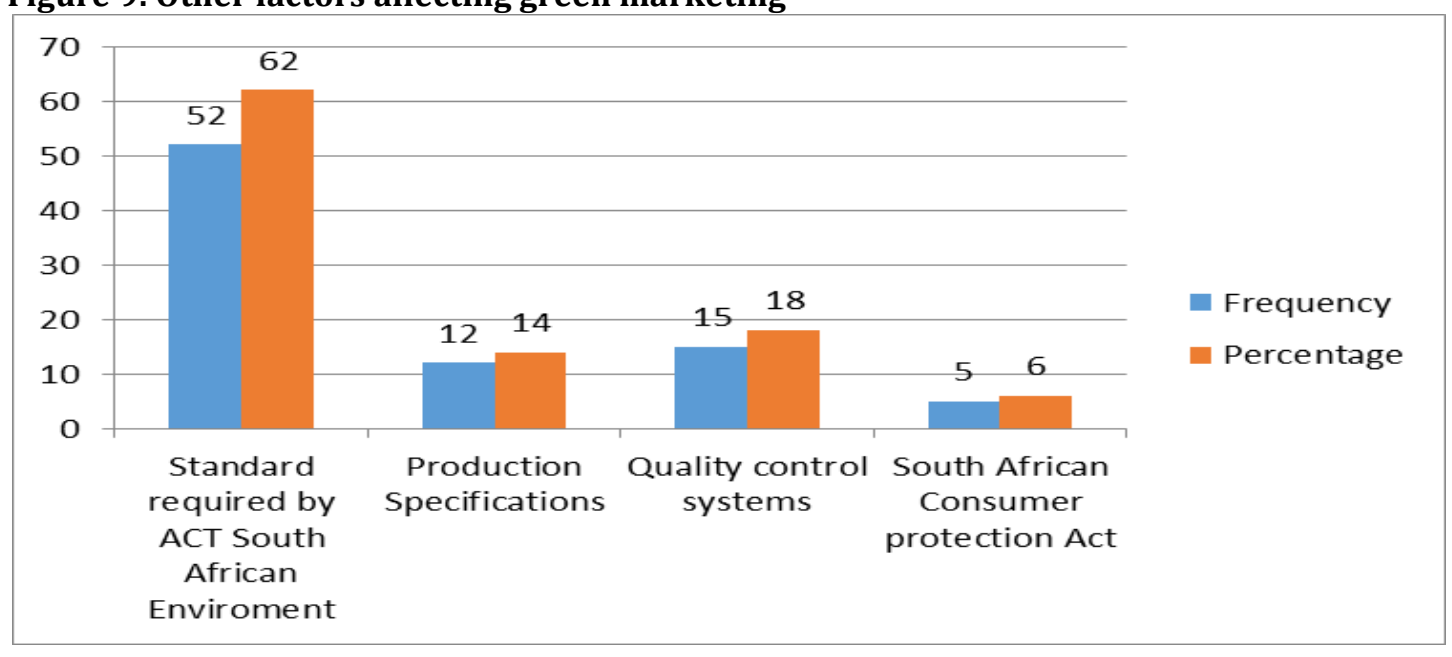

Figure 9 shows that the majority of the respondents 52 (62 percent) mention that standard required by South African environmental act has influencing on their day -to-day green marketing activities. While less than half of the respondents mention 12 (14 percent) product specifications, 15 (18 percent) and five (six percent) South African consumer protection act.

Limitations: The limitations of this research need to be acknowledged and taken into account, before any recommendations are made. The sample size that was used was very small $(n=84)$, therefore, variables identified cannot be generalised to be representative of all South African manufacturing SMMEs, including other provinces. Since the sample size is so small, it is evident that not all South African manufacturing SMMEs were approached. The results cannot, therefore, be representative of all Manufacturing SMMEs in South Africa.

Implications: The implications for this research include issues related to three variables, being that of managerial, green marketing theory and green marketing practice.

Managerial implications of green Marketing: A green marketing approach promotes the integration of environmental issues into all aspects of the corporation's activities, including strategy formulation, planning, and production and dealings with consumers. Czinkota \& Ronkainen (1992) propose that, "corporations will have to find solutions to environmental challenges through marketing strategies, products and services, in order to remain competitive". These include new technologies for handling waste, sewage and air pollution; product standardisation to ensure environmentally safe products; providing 'truly' natural products; and products oriented toward resource conservation and greater occupant health (Czinkota \& Ronkainen, 1992). These solutions assure the company of a legitimate role in providing society's needs, as well as the opportunity to achieve industry pre-eminence (Murray \& Montanari, 1986). Although these changes could be seen as threats and/or added expense, far-sighted individuals within business firms are realising that, for those ready to recognize and capitalize on them, there are also real opportunities in environmental developments. The cost of new laws and regulations, endless litigation, and the potential loss of competitive positions, should encourage marketers to assess these integral and critical components of an ecological, and environmentally friendly approach (Coddington, 1993, Frause \& Colehour, 1994). In addition, the implications of a potential loss of corporate and product credibility, due to perceptions of inaction, should be meticulously considered by firms, including, for example, totally evading any environmental initiative, or forced compliance, such as environmental actions being practised only when it is a directive of regulations.

Kleiner (1991) asserts that people are obstructed when attempting to change corporations from within, in any fundamental manner. "Corporate culture and political pressures provide almost insurmountable resistance against any sudden and even enlightened change" (Frause \& Colehour, 1994). It is advocated 
by Frause \& Colehour (1994) that, the solution to this predicament perhaps lies between "saving it all" (limits to growth environmentalism), and "using it all" (rampant entrepreneurship). It then becomes a matter of educating managers, regarding cost-benefit on the one hand, and social responsibility on the other hand, i.e. the organisations' place and responsibilities, as active members of the collective system they operate in.

Implications for green marketing theory: Having established an understanding of green marketing in describing its background, it is clear why green marketing is an important subject in contemporary society. The definitions of what green marketing is, and the role that established green marketing strategies play, explain the importance of green marketing as used in different marketing scenarios, in order to produce products that are strongly appealing to green consumers. It also reflects how it influences green purchasing behaviour; South African manufacturing SMEs need to understand green marketing concepts in order to implement it properly. Knowledge and in-depth understanding of relevant green marketing theory, green consumer buying behaviour theory, and green consumer, post purchase behaviour, will result in the increase of individual SMEs brand choice and market share. SMEs owners/managers will use this study and understanding of it, as an applied green marketing related, dayto-day marketing strategy as this is limiting the contribution to the marketing theory.

Implication for green marketing practice: According to Walker \& Hanson (1998), the characteristics of green marketing practice are found in a genuine concern for the nature of inputs, as well as outputs. With inputs, it is meant to include sources of supply, consumption of resources, and design of products and production. Outputs then include the use, durability and disposability of products, waste and pollution, attitudes, expectations and behaviour of the customer/consumer, and the current and future impact on the environment and society as a whole, by these factors. On the practical side, the findings of this due to the high costs of green marketing specialists SMEs do not fully implement green marketing programmes all the times. Eco-labelling of green products also has costs and skills implications for the SMEs, as this requires them to have specialist skills. Distribution of green products and the price of green products further affect the SMEs market share percentage.

\section{Conclusion}

The research demonstrated that there is a need for South African manufacturing SMEs to increase green marketing awareness and understanding of green marketing concept benefits to the sector and its target market. The study further identified the lack of skilled marketing personnel as a major barrier facing their companies, with regard to practicing green marketing. It has been established that a lack of marketing specialists within the SME industry, forces owners/managers to acquire the services of marketing consultants, with some of these services being very expensive. On the other hand, the research indicated that the lack of understanding and knowledge of marketing has made SMEs green marketing activities more costly. It was further noticed that, due to the green marketing of SMEs products, price increases have negative implications for both customers and companies. This is because of an increase in the cost of packaging material required for green geology products and eco-labels of products. There are also some serious concerns among the respondents, with regard to other complex factors affecting green marketing activities, such as quality control standards specification requirements and standard authority approval, where most of time some of the SMEs have to hire consultants to help with assessment specifications needed by the South African Act.

Recommendations: There is a clear indication from the findings that much still needs to be done by South African SMEs and some negative implications have been identified. Therefore, this study recommends that SMEs should participate in training programmes, in collaboration with government training centres and public training institutions. This would include universities and new government venture further education and training (FET) facilities, so that they are able to do on-the-job training for their staff. The study also recommends that SMEs owners/managers should conduct customer training about green products. As a result, more awareness will be built, with regard to green marketing, among target markets and consumers will not have to rely only on information provided on packaging material. 


\section{References}

Azad, N., Nobahari, S., Bagheri, H., Esmaeeli, M. \& Rikhtegar, M. (2013). An exploration study on factors influencing green marketing. Management Science Letters, 3(5), 1367.

Bukhari, S. S. (2011). Green Marketing and its impact on consumer behaviour. European Journal of Business and Management, 3(4), 1.

Carroll, A. B. \& Buchholtz, A. K. (2000). Business \& Society, Ethics and Stakeholder Management, SouthWestern Publishing, Cinn., Ohio.

Chen, T. B. \& Chai, L. T. (2010). Attitude towards the environmental and green products: Consumer perspective. Management science and engineering, 4 (2), 27-39.

Coddington, W. (1993). Environmental marketing: positive strategies for reaching the Green consumer, New York: McGraw-Hill.

Czinkota, M. \& Ronkainen, I. (1992). Global marketing: A marketing survival guide. Marketing management, 1(1), 36-45.

Da-Silva, I. S. (2010). Is green marketing the future of business? [Online]. Available at: http://www.bizcommunity.com/Article/196/423/43446.html. (Accessed 23/02/2014).

Engel, D. (2008). Three stages to a greener company. [Online]. Available at: http://www.harmoniousliving.co.za. (Accessed 19/04/2014).

Finistera do Paco, A., Raposo, M. \& Filho, W. (2009). Identifying the green consumer: A segmentation study. Journal of Targeting, Measurement and Analysis for Marketing, 17(4), 17-25.

Frause, B. \& Colehour, J. (1994). The Environmental Marketing Imperative. Chicago: Probus Publishing.

Gale, F. (2006). Regulating the market in an Era of globalization: Global governance via the forest stewardship council. [Online]. Available at: http://eprints.utas.edu.au/455/1/APSA-06ForestGovernance.pdf?origin=publication_detail (Accessed 26/02/2014).

Ghoshal, M. (2008). Green Marketing A Changing Concept in Changing Time. [Online]. Available at http://www.scribd.com/doc/12859654/Green-Marketing. (Accessed 18/04/2014).

Gurmeet, S. H. (2013). A study of evolution and practice of green marketing by various companies in India. International Journal of Management and Social Sciences Research, 2(7), 49-56.

Hashem, T. \& Al-rifai, N. (2011). The influence of applying green marketing mix by chemical industries companies in three Arab States in West Asia on consumer's mental image. International Journal of Business and Social Science, 2(3), 92.

Horne, R. E. (2009). Limits to be labels: The role of eco -labels in the assessment of product sustainability and routes to sustainable consumption. International of consumer studies, 33(6), 175-182.

Humphreys, D. (2008). The Politics of 'Avoided Deforestation': Historical Context and Contemporary Issues. International Forestry Review, 10(3), 433-442.

Iravania, M. R., Zadehb, M. S., Foroziac, A., shafaruddind, N. \& Mahroeiane, H. (2012). Study of Factors Affecting Young Consumers to Choose Green Products. Journal of Basic and Applied Scientific Research, 2(6), 5534-5544.

Juwaheer, T. D., Pudarah, S. \& Noyaux, M. M. E. (2012). Analysing the impact of green marketing strategies on consumer purchasing patterns in Mauritius. World Journal of Entrepreneurship, Management and Sustainable Development, 8(1), 36-59.

Kassinis, G. \& Vafeas, N. (2006). Stakeholder pressures and environmental performance. Academy of Management Journal, 49(5), 145-159.

Kinoti, M. M. (2011). Green marketing Intervention Strategies and Sustainable Development: A Conceptual Paper. International Journal of Business and Social Science, 2(23), 263.

Kleiner. A. (1991). What does it mean to be Green? Havard Business Review, 3, 4-11.

Kleindorfer, P. R., Singhal, K. \& Wassenhove, L. N. V. (2005). Sustainable operations management. Production and Operations Management, 14(4), 482-492.

Kontic, I. (2010). Greening the marketing mix: A case study of the Rockwool Group. [Online]. Available at: http://www.diva-portal.org/smash/get/diva2:329044/FULLTEXT01.pdf. 18/03/2014).

Kotler, P. (2000). Marketing management analysis, Planning, implementation and control, 9th edition, prentice hall. INC.

KZN Manufacturing sector. (2014). Manufacturing Sector. [Online]. Available at: http://kzntopbusiness.co.za/site/manufacturing (Accessed 25/03/2014).

Lee, H. \& Park, S. (2013). Environmental orientation in going green: A qualitative approach to consumer psychology and sociocultural factors on green consumption. Journal of global scholars of marketing science: Bridging Asia and the world, 23(3), 245 - 262. 
Mishra, P. \& Sharma, P. (2010). Green marketing in India: emerging opportunities and challenges. Journal of Engineering, Science and Management Education, 3, 9-14.

Mohanasundaram, V. (2012). Green marketing - challenges and opportunities, International Journal of Multidisciplinary Research, 2(4), 66-73.

Murray, K. B. \& Montanari, J. R. (1986). Strategic Management of the Socially Responsible Firm: Integrating Management and Marketing Theory. Academy of Management Review, 11, 815-827.

OECD working party on SMEs and entrepreneurship (WPSMEE). (2010). SMEs and Green Growth: Promoting sustainable manufacturing and eco-innovation in small firms. [Online]. Available at: http://www.oecd.org/cfe/smes/46404383.pdf. (Accessed 26/04/2014).

Ottman, J. A., Stafford, E. R. \& Hartman, C. L. (2006). Avoiding Green Marketing Myopia: Ways to Improve Consumer Appeal for Environmentally Preferable Products, Environment. Science and Policy for Sustainable Development, 48 (5), 22-36.

Peattie, K. (1995). Environmental Marketing Management: Meeting the Green Challenge (Paperback), London: Financial Times Prentice Hall.

Peattie, K. \& Crane, A. (2005). Green marketing: legend, myth, farces or prophesies? Qualitative Market Research. An International Journal, 8(4), 357 - 370.

Polonsky, M. J. (1994). An introduction to green marketing. Electronic green Journal, 1(2), 1.

Prakash, A. (2002). Green marketing, public policy and managerial strategies. Business Strategy and the Environment, 11, 285-297.

Saad, L. (2009). Did Hollywood's Glare heat up public concern about Global warming? Gallup news service. [Online]. Available at: http://www.gallup.com/poll/26932/did-hollywoods-glare-heatpublic-concern-about-global-warming.aspx. (Accessed 19/04/2014).

Saxena, R. \& Khandelwal, P. K. (2010), 'Sustainable development through green marketing: The industry perspective. The International Journal of Environmental, Cultural, Economic and Social Sustainability, 6(5), 59-79.

Shrikanth, R. \& Raju, D. (2012). Contemporary green marketing - brief reference to Indian scenario. International Journal of Social Sciences \& Interdisciplinary Research, 1(1), 26 - 39.

Smith, K., Lawrence, G. \& Richards, C. (2010). Supermarkets' governance of the agri-food supply chain: is the 'corporate-environmental' food regime evident in Australia. International Journal of society of agriculture and food, 17(2), 37.

Sorensen, E. \& Jacob, T. (2007). Theories of Democratic Network Governance. Palgrave Macmillan.

Thakur, K. S. \& Gupta, S. (2012). Exploration of Green Shift: Shift from trendy marketing to environmental friendly green marketing. International Journal of Arts and Commerce, 1(7), 1.

Van Wyk, A. \& Deegan, W. (2009). Executive Guide to King III, [Online]. Available at: http://www.pwc.co.za/en/king3/ (Accessed 23/01/2014).

Williamson, A. (2013). Green Marketing for Eco-Friendly Businesses. [Online]. Available at:http://www.environment.co.za/sustainable-green-business-news/green-marketing-for-ecofriendly-businesses.html. (Accessed 23/02/2014).

Walker, R. H. \& Hanson, D. J. (1998). Green Marketing and Green Places: Taxonomy for the Destination Marketer. Journal of Marketing Management, 14 (6), 623-639.

Yurman, D. (1994). Green Technology Markets; Opportunities, Barriers \& New Paradigms, [Online]. Available at: http://courses.cs.vt.edu/cs3604/lib/GreenMachines/Yurman.html. (Accessed 20/01/2014). 